LA $-9282-M S$

DE82 016374

\title{
Los Alamos Plutonium Facility Implementation Support Project Report
}

C. C. Thomas, Jr.

W. Ford

S. T. Hsue

R. S. Marshall

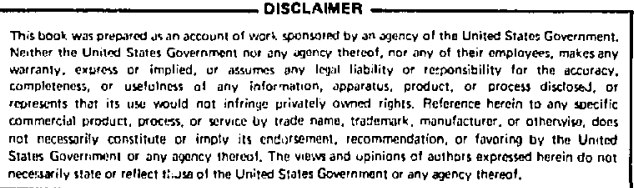

Stales Government or any agency inerest. The views and upinions of authors expressest the Unitod necelsarily stare or refliect tidse al the United Siales Government or any agency thergal.

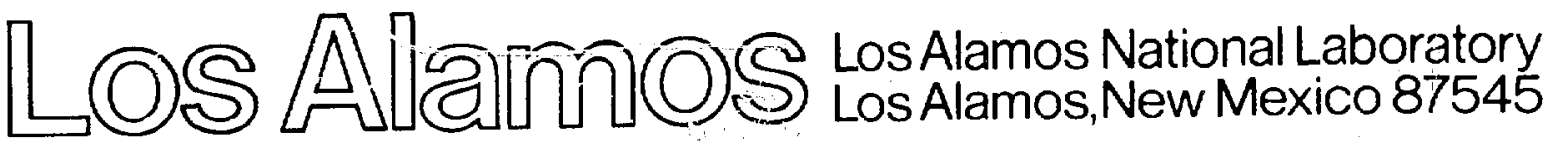


LOS ALAMOS PLUTONIUM FACILITY

IMPLEMENTATION SUPPORT PROJECT REPORT

by

C. C. Thomas, Jr., W. Ford,

S. T. ssue, and R. S. Marshall

\section{ABSTRACT}

During FY $198 . \mathrm{l}$ the TA-55 Implementation Support Project provided assistance to the Los Alamos Plutonium Facility in materials accounting and control, including

- testing and evaluation of a solution mass measurement system,

- development and testing of a lowlevel plutonium assay system,

- holdup measurements,

- instrument design, and

- advice and consultation following the observation of semiannual inventories.

This report describes the program envisioned for FY 1982, including

- defmonstration of the solution mass misasurement system and the associated calibration system,

- Extension of the low-level plutonium assay system to solutions with americium/plutonium ratios of 10 : to $20: 1$, and

development and demonstration of a method to calibrate and routinely verify the plutonium oxalate assay instrument performance.

The FY 1982 program is subject to changes basfd on TA-55 reevaluation of facility neels. 
The objective of the TA-55 Implementation support Project is to provide materials accounting assistance to the Los Alamos Plutonium Facility (TA-55) manager upon request. This report briefly summarizes the assistance provided from october 1, 1980 through September 30, 1981 (FY 1981). Assistance to be provided during FY 1982, also defined in this report, is based on an estimate of support from the office of Safeguards and Security (OSS) Implementation Support program.

II. FY 1981 ACTIVITIES

A. Solution Mass Measurement (Pressure Transducer)

The implementation support effort during this report period was devoted primarily to the test and evaluation ( $T \& E$ ) of pressure transducers for measuring liquid mass and the concomitant $T \& E$ of a gravimetric prover for tank calibration. A detailed report describing this effort is in press. ${ }^{1}$ our effort is summarized briefly in the following paragraphs. We plan limited additional effort to convert the laboratory test bed and calibration system to a demonstration plant-prototype, which is scheduled for initial demonstration in the first quarter of FY 1982. A pressure transducer was interfaced to a solution assay instrument (SAI) and will be incorporated in the prototype demonstration unit.

Using weighted samples and an SAI, we determined the concentration of plutonium in solutions contained in vertical Pyrex tanks. The mass of the bulk solution is needed to calculate the total plutonium content of the tank. Alternatively, the sample can be analyzed on a volumetric basis, and the tank plutonium content can be calculated from the volume of the solution. We selected the mass method for the Dynamic Materials Accounting system in the Los Alamos Plutonium Facility.

Initially, we investigated tank weighing methods that were based on the use of load cells. However, the tank mounting and 
stirring mechanism interfered with such systems. A mass measurement system based on the pneumatic bubbler-tube method was then selected for T\&E under the glovebox conditions at the Los Alamos facility.

Initial facility design specified that solution transfers in gloveboxes would be accomplished by vacuum techniques. To ensure maximum accuracy and adequate pressure tolerance, we selected pressure transducers with a $0-5$ psi working range and a -10 to t10 psid maximum range. Shortly after facility start-up, a solution transfer procedure involving pressurization of the sending tank was initiated to improve solution transfer rates. Air pressure up to 30 psid was used, exceeding the pressure transducer safe overpressure limits, and many of the units were damaged. Furthermore, in a few instances solution was drawn up the dip tube into the transducer pressure port during solution transfer.

Because of problems with the original transducer installation, a test bed was fabricated to test transducers under simulated operating pressure conditions but using non-plutonium-containing solutions. Initial tests with this system established transducer requirements. Five transducers, including the orjginally specified model, were tested. The original model failed mechanically; aithough it performed well in carefully controlled conditions, it was not adequate over the full test pressure range. The other four units performed satisfactorily under actual conditions. Three of the units have large pressure-port cavities and require provisions to prevent solution accumulation in the cavity. The fourth transducer is a variable-reluctance type with built-in electronics to simulate a strain-gage bridge; it is the most favorable unit because of its small cavity, which does not collect solution.

The resolution of the electronics is 3 parts in $10^{4}$. Drifts, noise, analog-to-digital conversion error, and other effects limit the accuracy to 9 parts in $10^{4}$. We made calibration runs using weighed quantities of water. An additional calibration on the experimental test bed was made with a precision 
pressure gauge (Ruska DDR 6000)*, which was incorporated into the tank calibration system. Solution is pump transferred from a well-calibrated stainless-steel tank to the test tank, and the Ruska determines the mass of solution transferred. The uncertainty in the amount transferred is $\sim 1$ part in $10^{4}$ for calibration of the system.

\section{B. Low-Level Plutonium Assay System}

Primary support to develop the low-level $(0.001$ to $1 \mathrm{~g} / \mathrm{L})$ plutonium assay system was provided by the oss instrumentation program with limited support from the TA-55 Implementation support task. The following paragraphs summarize the development and T\&E effort to date. A paper describing the system and system performance/was presented at the Institute of Nuclear Materials Management annual meeting (San Francisco, July 13-17, 1981).2 Our future efforts will be directed towards determining low levels of plutonium in solutions with americium/plutonium ratios of $>2$ : to $3: 1$, which is the upper limit evaluated to date. A separation step may be required for solutions with higher americium/plutonium ratios.

The low-level plutonium assay system is under T\&E in the research and development facility at TA-55. The system was developed to assay effluent solutions from the anion-exchange columns used in recovering plutonium. These effluents nominally have a low plutonium concentration $(<100 \mathrm{mg} / \mathrm{L})$ and a high americium concentration relative to the plutonium (americium/plutonium $\sim_{1}$ to 20). Effluent solutions with concentrations $>20 \mathrm{mg} / \mathrm{L}$ are reprocessed for further plutonium recovery, and those $<20 \mathrm{mg} / \mathrm{L}$ are transferred to acid recovery.

The nondestructive assay (NDA) system is based on measuring the L-x rays following alpha decay. Preliminary results indicate that an average deviation of $30 \%$ between $L-x$ ray and alpha counting can be achieved for plutonium concentrations $>10 \mathrm{mg} / \mathrm{L}$ and americium/plutonium ratios of up to 3 (Fig. 1). For plutonium concentrations of $1-10 \mathrm{mg} / \mathrm{L}$ the average deviation between the two

*Manufactured by Ruska Instrument Corporation, 6121 Hillcroft, Houston, TX 77036 . 


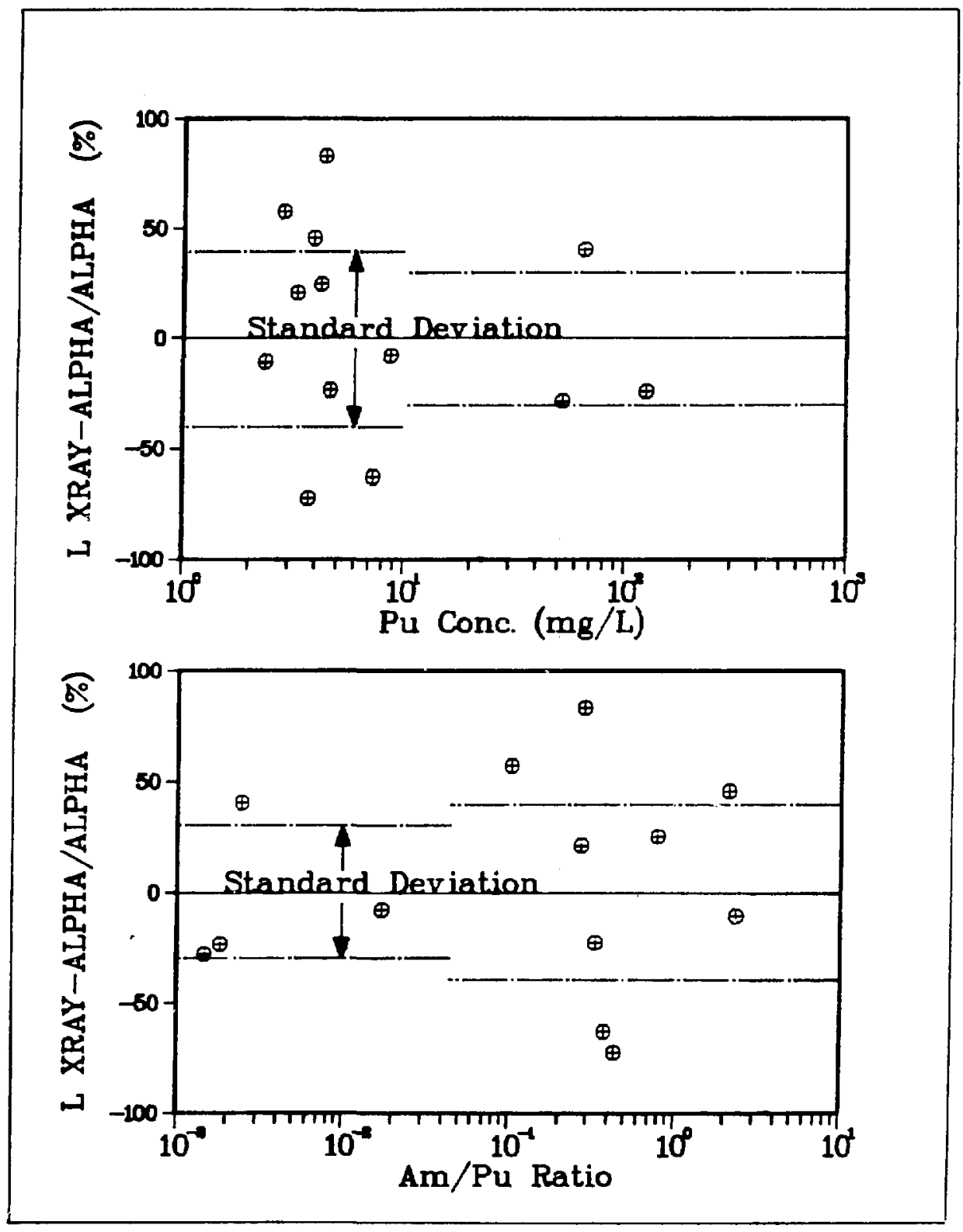

Fig. 1. Comparison between analysis using $\mathbf{L}-\mathbf{x}$ ray and alpha counting (a) as a function of plutonium concentration and (b) as a function of americium/plutonium ratios. 
methods is 408 (Fig. 1). The detection limit of the L-x-ray assay is $\sim 1 \mathrm{mg} / \mathrm{L}$. We are continuing to evaluate the NDA assay using isotopic-dilution mass spectrometry because the alpha counting method has a relatively large uncertainty; its precision is claimed to be wlos.

\section{Additional Activities}

We made glovebox and equipment holdup measurements in response to TA-55 management requests. This activity required one to two man-weeks of effort.

We undertook three tasks in support of plutonium enrichment projects. (1) A preliminary design of an instrument for the R\&D phase of the project was recommended, and the instrument is now being developed with non-oss funding. (2) We recommended the preliminary design of an instrument to be used in the pilot plant. (As a result of funding uncertainty, further effort on the pilotplant instrument has been curtailed.) (3) We located plutonium holdup areas within the experimental apparatus using a NaI(TI) dual-channel-analyzer system. Approximately one man-month of effort was devoted to these three tasks.

Typically, a shutdown and cleanout inventory loses several weeks of production, whereas the rundown inventory can be completed in <2 days. PF/LASS data are now being analyzed in an effort to provide an alternative to complete a shutdown and cleanout for each bimonthly and annual inventory. Department of Energy regulations make provision for the concept, and two limited demonstrations were carried out at Los Alamos in FY 1982 with satisfactory results. In each inventory the involved processes were rundown and material was put into a sampled and measured form; the processes were temporarily shut down but not completely cleaned out. For the first demonstration in February 1981, safeguards $R \& D$ personnel provided advice and consultation on NDA measurement verification and instrumentation performance assurance. During the August 1981 demonstration, safeguards $R \& D$ personnel acted as observers in addition to providing technical advice and consultation. Three to four manweeks were committed to this effort. 
III. FY 1982 PROGRAM

This section outlines the FY 1982 program and milestones; this planning document also fulfills the october 1981 milestone for this project.

A. Solution Mass Measurement (Pressure Transducers)

We will convert the laboratory test-bed system to an inplant prototype. After limited testing, the system and the associated calibration will be demonstrated for operational personnel. If an interest develops for in-plant T\&E of the solution mass measurement and calibration systems, we will develop an appropriate program. If there is insufficient interest, the prototype unit and calibration system will be maintained for training purposes. The demonstration is scheduled for the first quarter of FY 1982.

\section{B. Low-Level Plutonium Assay System}

The present version of this instrument can determine low concentrations of plutonium in the presence of relatively high concentrations of americium (americium/plutonium ratios of 2: to 3:1). We anticipate that, in the future, americium/plutonium ratios up to 20 will be encountered in low-level plutonium recovery solutions, and we will modify the measurement techniques for such solutions. We are considering using solvent extraction of the plutonium and in situ measurement of the plutonium in the organic layer with a well-collimated detector.

C. Wet-oxalate Cake Plutonium Measurement

To determine the plutonium content of wet-oxalate cake, 3,4 wa use a passive neutron counting technique with a double-ring thermal neutron coincidence counter. The ratio of neutron counts between the two detector rings provides a signal needed to correct for the sample's water content. We obtain a calibration curve with $\mathrm{PuO}_{2}$ standards. The ring-ratio correction is obtained by counting several batches of wet plutonium oxalate, sampling each batch, and destructively analyzing the samples for plutonium. An alternative calibration technique involves measuring wet plutonium 
oxalate batches, combining pairs of batches, and calcining the combined batches to $\mathrm{PuO}_{2}$. We weigh the $\mathrm{PuO}_{2}$ and multiply the weight by a plutonium assay factor to obtain the plutonium mass. Uncertainties resulting from sampling the inhomogeneous batches of wet-plutonium-oxalate cake for destructive analysis are of the same magnitude as the uncertainties in the paired-batches technique; therefore the two calibration methods have about the same accuracy. Both methods are difficult and time-consuming, and therefore are undesirable for routine recalibration after instrument repair. To provide a more rapid method of calibration and routine verification of instrument performance, we are considering fabricating special standards to simulate plutonium oxalate cakes with provisions for varying the moderator (water) content.

D. FY 1982 Milestones

(1) Demonstrate solution mass measurement and calibration systems.

November 1981

(2) Extend low-level plutonium measurement technique to solution with americium/ plutonium ratios up to 10 : to $20: 1$.

August 1982

(3) Develop and demonstrate method for calibration and routine verification of performance of plutonium oxalate assay instrument. September 1982

(4) Document assistance provided to TA-55 manager. September 1982

\section{REFERENCES}

1. W. Ford, R. S. Marshall, L. Osborne, R. Picard, and. C. C. Thomas, Jr., "Solution Mass Measurement," Los Alamos National Laboratory report LA-9316-MS (May 1982).

2. S. T. Hsue, F. Hsue, and D. F. Bowersox, "Assay of Low-Level Plutonium Effluents," Nucl. Mater. Manage. $\underline{x}$, Proceedings Issue, 453-460 (July 1981).

3. R. S. Marshall and B. H. Erkkila, "The Measurement of Plutonium oxalate in Thermal Neutron Coincidence Counters," Proc. of Oak Ridge National Laboratory Conf. on Analytical Chemistry in Energy Technology, Gatlinburg, Tennessee, October 9-11, 1979 . 
4. R. S. Marshall and T. R. Canada, "An NDA Technique for the Assay of Wet Plutonium Oxalate," Nucl. Mater. Manage. IX, 107-113 (June 1980). 